Editon Consortium Publishing

Transforming Scholarly Publishing
Editon Consortium Journal of Arts, Humanities and Social Studies (ECJAHSS)

Volume: 01 Issue: 03 | Sep -2019

ISSN: 2663-8525

Received: 19.08.2019; Accepted 23.08.2019; published: 30.09.2019 at www.editoncpublishing.org

Njuguna, G.W., Editon Cons. J. Arts., Humanit. S. Stud., Double -Blind Peer Reviewed Journal

\title{
The Origin of European Settlement in Molo in the Early Colonial Period up to 1918
}

\author{
Grace Wanjiru Njuguna \\ Egerton University, Kenya \\ Email address: gracewanjiru488@yahoo.com
}

\begin{abstract}
The study examined the origin of European settlement in Molo in the early colonial period up to 1918 . The study commenced in the year 1904 when land alienation for white settlement in Molo started. It was also in 1904 when the first settlers, Major Webb and Jasper Abraham, settled in Mariashoni and Kweresoi (Kuresoi) in Molo area respectively. Settler dominance in Molo was essentially a consequence of discriminatory economic policies adopted by the colonial state. The white settlers aimed to make strides in agricultural production because of their cumulative experiences, availability of infrastructure, capital and government support. The Colonial Capitalism Theory guided this study. Data was collected from informants through oral interviews and from the Kenya National Archives in Nairobi. Informants were identified through snowball sampling. Secondary sources such as books, journals and articles were also used. Data was analysed historically, thematically and logically. Finally, data has been presented in a qualitative form, which is descriptive in nature.
\end{abstract}

Key Terms: Origin, European Settlement, Molo, Colonial Period

$* * *$

How to cite this article in APA ( $6^{\text {th }}$ Edition)

Njuguna, G.W. (2019). The origin of European settlement in Molo in the early colonial period up to 1918. Editon Cons. J. Arts., Humanit. S. Stud., 1(2), 81-91. $* * *$ 


\section{Editon Consortium Journal of Arts, Humanities and Social Studies (ECJAHSS)}

Volume: 01 Issue: 03 | Sep -2019

ISSN: 2663-8525

Received: 19.08.2019; Accepted 23.08.2019; published: 30.09.2019 at www.editoncpublishing.org

Njuguna, G.W., Editon Cons. J. Arts., Humanit. S. Stud., Double -Blind Peer Reviewed Journal

\section{Introduction}

The origin of European settlement in colonial Kenya evolved from an imperial concept of private enterprise. By the turn of the $19^{\text {th }}$ Century, the foreign office in charge of the protectorate was already complaining about the imperial grant-in-aid used for running the administration in Kenya and executing punitive military expeditions (Cone, \& Lipscomb, 1972). According to Kenyanchui (1992), European settlement was necessitated by the Uganda railway whose construction and maintenance cost would payback. Europeans regarded uninhabited land as "no man's land" and therefore available for settlement and exploitation by European settler farmers (Kenyanchui, 1992). In 1901, Lipscomb argues that since Kenya had no valuable natural resources to exploit to repay investment which had been made on the railway, settler farming was thus to be encouraged. Therefore, European settlers would farm the idle land along the railway to pay back for the investment (Huxley, 1957). Settler agriculture was introduced because of economic, political and geographical factors. The Kenya-Uganda Railway had opened up the country to the outside world (Cone, \& Lipscomb, 1972). The European settlers would generate incomes that would pay off both the cost of investment in the railway and its maintenance. European agriculture would also generate revenue for running the colonial administration.

This idea of generating revenue became the justification for Europeans settlerdom in colonial Kenya. As a result of British settlement, the British government assumed full ownership over all land in the colony. Thus customary tenure of land was disregarded and the legislation that followed hardly incorporated customary laws. From the start, the land laws were designed to serve the interests of white settlers, who were expected to support the Uganda railway infrastructure (Wolff, 1970). The period 1985-1923, according to Wringley (1965), constituted the formative years in the evolution of settler agriculture. It was a period of land alienation and experimentation in agriculture.
Crops such as coffee, wheat, cotton and maize were planted. Sisal, coffee and maize were more successful. Wheat, flax, rubber and livestock rearing proved unsuccessful by 1914. The white settlers were given official support, and they were confident of creating a 'white man's country.' The wealthy ones set up high standards in farming and living (Wringley, 1965). However, farming was inefficient in the early days in the colony. The settlers lacked capital and technology, as well as labour. The white settlers were also frustrated by price fluctuations, particularly before the First World War.

The period before and during the First World War was characterized by the introduction of new crops such as coco beans and English potatoes. The agricultural profitability continued throughout the First World War despite war conditions and the fact that some farms reverted to bush as their owners went to war. The period after the First World War was characterized by rapid economic advance. Farmers were making profits; profits generated further investments, and investment generated further increases in income. A period of sustained growth began (Kenyanchui, 1992). European farming in Molo during this early period was rudimental, with scattered pioneers being land occupiers rather than farmers. Many settlers were essentially subsistence cultivators. Many settlers arriving in Molo were not concerned with the local planting season, which led to the failure of some planted crops. Powys was interested in developing mixed farming, but he did not have enough resources.

By 1914, with the help of Mark Call, Gerry Alexander owned close to fifteen thousand sheep, which included some purebred merinos. However, Gerry began to find the size of the flock unmanageable since the sheep market was not good at that time. Gerry ended up opening his own butchery in Lower Molo (Powys 1969). However, Powys fails to show how settlers such as Rutherford ventured into 


\section{Editon Consortium Journal of Arts, Humanities and Social Studies (ECJAHSS)}

Volume: 01 Issue: 03 | Sep -2019

ISSN: 2663-8525

Received: 19.08.2019; Accepted 23.08.2019; published: 30.09.2019 at www.editoncpublishing.org

Njuguna, G.W., Editon Cons. J. Arts., Humanit. S. Stud., Double -Blind Peer Reviewed Journal

large-scale wheat and barley farming. Much of the work by Powys concentrates on sheep farming and marketing.

\section{The Origin of European settlers in Kenya}

In 1895, Kenya was declared a British protectorate. The first regulation of the East Africa Protectorate was published as early as 1897 by the Majesty's court of East Africa, which was later, renamed the High Court of East Africa. However, little land alienation took place until after the construction of the Kenya-Uganda Railway. The railway reached Nairobi in 1899 and eventually reached Lake Victoria in 1901. The British government felt that if farming was encouraged in Kenya, it would help pay for the territory's administration and keeping the railway busy (Kenyanchui, 1992). The cool climate and absence of population over large areas of the highlands also encouraged European settlement. Settlement in Kenya was achieved largely through the efforts of the newly appointed High Commissioner, Sir Charles Eliot, and a few newly arrived settlers. Eliot's dream for the new territory was that it would be developed as a 'white man's country' (Wunyambari, 1993). Molo was a thick forest, inhabited by a sparse population of the hunting and honey collecting Ndorobo. The cool climate and ample rainfall made the area amenable to white settlement and encouraged rapid settlement.

In 1903, free grants of land were offered to white settlers in Molo. Although the 640-acre arable land blocks were taken up easily, the 5,000-acre ranches were not. However, the settlers who occupied the 640-acre blocks later moved to Londiani before they had even cleared the land for farming. In 1904, more white settlers arrived in the Molo area, particularly from South Africa and Britain. Another major allotment of land was made. The first settlers started by cultivating large areas of land in Kweresoi (Kuresoi), Mariashoni and later Turi area (Curtis, 1986). Before the introduction of colonial rule in Kenya, the Ogiek also referred to as the Ndorobo, were the indigenous people living in Molo. According to Towett, the Ogiek form a minority group among the Kalenjin.

The Ogiek were mostly hunters and gatherers who inhabited the forested area of the Mau forest. Apart from hunting wild animals and birds for food, the Ogiek also gathered plant food and honey (Towett, 2004). The pastoral Maasai had come grazing in Molo, and their cattle died due to an unknown disease. The Maasai named the place Molo, meaning a 'curse' (Muiruri, 2013). With the arrival of white settlers in Molo, the traditional system of agriculture began to change. New crop varieties, livestock breeds and improved tools revolutionized agriculture in Molo. The crossbreeding of zebu with Ayrshire, Jersey and Friesian improved the pedigree and as a result milk production increased. However, all these changes affected the indigenous groups in Molo. Africans were pushed out of their land, hired as labourers and paid taxes, all of which aimed at making settler agriculture successful.

By 1905, Mariashoni, Turi and Matumaini areas of Molo had become reserved solely for white settler farmers. The Africans were confined to the reserves. Economic interests were racially depicted from an early stage, involving conflict over land and labour between the white settlers and the Ogiek. The land alienated for the settlers was carved out of the most fertile areas and close to the railway (Lewis, 2013). Intervention by the government on behalf of the settlers' was decisive, with differing views over policy implementation not detracting from the active collaboration between colonial officials and settlers representatives (Best, 1970). By the First World War, farmland in Molo remained rather distinct blocks separated by forest reserves. Later, Molo area turned to be a wellestablished settler community famous for sheep farming (Molo lamb) (Lewis, 1963). Curtis argues that it took several years of trial and error, plus quite incredible losses, to establish staple sheep farming in Molo. Later on, Major Webb and Stanton acquired merino sheep from Australia 


\section{Editon Consortium Journal of Arts, Humanities and Social Studies (ECJAHSS)}

Volume: 01 Issue: 03 | Sep -2019

ISSN: $2663-8525$

Received: 19.08.2019; Accepted 23.08.2019; published: 30.09.2019 at www.editoncpublishing.org

Njuguna, G.W., Editon Cons. J. Arts., Humanit. S. Stud., Double -Blind Peer Reviewed Journal

and New Zealand, which were crossbred with the local Maasai sheep.

The settlers aimed to introduce a pedigree sire to use on the indigenous animals in order to get better size and quality breeds (Curtis, 1986). However, the settlers met with mixed fortunes. The Molo sheep were resistant to diseases and were more marketable as compared to the local Maasai sheep (Powys 1969). An early decision was taken by the colonial governments to stimulate white settler agriculture as the basis of change. The colonial state set measures providing the legal conditions necessary for the establishment of the estates and some of the economic conditions to ensure productivity. Due to unknown environmental conditions and financial challenges, largescale farming had failed to progress.

According to Lewis, barley farming in Molo gave the settlers higher returns. Less labour was required as mechanization had replaced human labour. Stanton ventured in pyrethrum farming before the outbreak of the Second World War. Pyrethrum was well adapted to the climatic conditions in the area and did not require many chemical inputs. Stanton easily acquired labour from the squatters and their children. However, Stanton faced the challenge of drying the flowers since he relied on artificial drying (Lewis, 2013). Settler agriculture in Molo was mixed farming that is both livestock keeping and crop production. Through the entire colonial period, settler farming gradually improved from rudimental farming tools to improved farming equipment, improved seeds and seedlings, use of fertilizers and availability of labour to work in the farms. One important aspect of Kenya's history during the colonial era was the process of agrarian transformation in areas of white settlement. Molo area, in particular, experienced many agricultural changes. Factors such as the introduction of new crops and new animal breeds, as well as new technologies and innovations, contributed to this transformation. These changes were the subject of the study.

\section{Theoretical Framework}

This study employed the Colonial Capitalism Theory. Van Zwaneneberg formulated this theory. The colonial mode of capitalist production was dependent upon the imperial state in all major areas of economic growth. That is finance, banking, trade, markets, technology, science, personnel, education and in the political and administrative mechanism. The colonial state determined the form and mode that capitalist production took. This mode was used to produce commodities for the market, employed wage labour and was dependent on finance capital. In Kenya, the politically powerful landed oligarchy from Britain used their influence with the imperial government to ensure that it should be they who mobilized capital in order to initiate new techniques in agriculture (Zwanenberg, 1975).This theory further argued that the white settlers were offered access to African land by the colonial state, which failed to provide sufficient wage labour or finance capital. The colonial government in Kenya passed a great deal of legislation, which supported the needs of the settler farmers to develop capital.

The period between the First and the Second World Wars was characterized in Kenya by a constant struggle between the white settler and the Africans people. Adequate financial accumulation, adequate for capital accumulation, could only occur through the extraction of a productive surplus from the labour of the African people. Myint argued that the plantation mode of production failed to become the leading sector, due to the cheap labour policy, which restricted technological innovation because it was the dominant sector. The plantation sector of the economy required cheap labour in order to accumulate surplus value, which was the prerequisite for technical innovation (Myint, 1964). 


\section{Editon Consortium Journal of Arts, Humanities and Social Studies (ECJAHSS)}

Volume: 01 Issue: 03 | Sep -2019

ISSN: $2663-8525$

Received: 19.08.2019; Accepted 23.08.2019; published: 30.09.2019 at www.editoncpublishing.org

Njuguna, G.W., Editon Cons. J. Arts., Humanit. S. Stud., Double -Blind Peer Reviewed Journal

Due to lack of voluntary labour, a series of taxes and laws to make or less force the native population into services were enacted. The alienation of African lands and the restrictions imposed on natives as to what they were allowed to grow on lands neighbouring settlements ensured they would not be able to maintain a livelihood unless they resorted to working for the settlement. A hut tax was introduced in 1920 as a mechanism for raising government revenue as well as a way of inducing Africans to work for white settlers. In 1908, a poll tax charged on all Africans over the age of 16 years was introduced.

However, labour shortages persisted, and the use of forced labour during the First World War enacted. In 1920, the colonial state came up with the Native Registration Ordinance (NRO) which enabled it to control African labour by forcing all Africans males, all 16 years and above to carry Kipande (Passbook) which showed the address of the bearer employer as well as his wages (Kanogo, 1987). The colonial state played a fundamental role on settlers' behalf by appropriating African land, confiscating livestock, and introducing taxation to Africans, building rail and transport networks and creating forced labour marketing and financial structures highly favourable to the white settlers (Ochieng, 1989). However, this theory had weaknesses as it failed to show the characteristic of the colonial pattern of development in an export economy.

These colonial patterns which either developed largely economically, underdeveloped hinterland. The export economy develops in the first place because the orthodox theory and the practical needs of the invading country happen to coincide. The theory demands a positive balance of payments, and as there is no internal market, it is necessary to develop products, which can be exported. Lenin argued that it is that the poverty of the underdeveloped world was due to this process, which starves the domestic economy of cash, and limits the opportunities for profitable investment (Levin,
1960).Further criticism of the theory argued that the development of the export sector was understood to be closely related to the underdevelopment of the indigenous sector. In the case of Kenya, the evidence strongly indicated that the development among the large white settler farm included major developments among the local African economies.

In a broad sense, the economic underdevelopment of the indigenous sector was a precondition for the growth of the settler economy, although the existence of the white settlers provided a market for a part of the indigenous economy (Zwanenberg, 1975).However, this criticism needed to be modified, as it did not show the relation between the capitalist and pre-capitalist sectors. Moreover, a portion of Kenya's indigenous economy benefited from the economic opportunities presented by the demands of the white settler farmer economy. Hence this theory helped understand the form and the mode of capitalist production, which was determined by the colonial state.

\section{Methodology}

This study was done in Molo, located in Nakuru County, Kenya. The study employed a historical research design. This research design was selected to help the researcher integrate the different components of the study in a coherent and logical way. Primary sources were used to collect data. Official records such as District annual reports and agricultural reports were used. These documents provided historical data on land tenure and land policies, taxation, market, agricultural policies and the types of crops that were grown in the Molo area. Secondary sources such as books, articles journals and conference papers were also consulted. These sources helped the researcher to broaden the research by providing background information, analyses and various perspectives beyond what the primary sources provided. The research relied on interview schedule and observations. The oral 


\section{Editon Consortium Journal of Arts, Humanities and Social Studies (ECJAHSS)}

Volume: 01 Issue: 03 | Sep -2019

ISSN: 2663-8525

Received: 19.08.2019; Accepted 23.08.2019; published: 30.09.2019 at www.editoncpublishing.org

Njuguna, G.W., Editon Cons. J. Arts., Humanit. S. Stud., Double -Blind Peer Reviewed Journal

interview involved informants were identified through sampling technique. Informants selected through the sampling technique were knowledgeable people in order to give the information required. In that case, the snowballing technique was applied. The interviewed informant hence recommended the researcher to another informant, who was knowledgeable about the agricultural transformation of settler agriculture in Molo. The interviews were guided by a set of questions constructed by the researcher. The study utilised the non-probability sampling method, which comprised of snowball sampling. The study targeted to interview about seventy-five informants who were knowledgeable about the transformation of white settler agriculture in Molo. This included twenty-four from Elburgon, twenty from Marioshoni, Twelve from Turi and nineteen from Molo Township. The researcher interviewed all the informants despite their geographical location. This included the residents of Mariashoni, Molo, Turi and Elburgon.The historical method was used in analyzing and interpreting data. The use of historical methods infers Garragham, leads to knowledge that is uniquely historical. This method involved the analysis and explanation of harnessed data both historically, logically and thematically.

\section{Research Findings}

\section{Early White Settlers in Molo up to 1918}

Kenny argues that the description by British explorers and photographs from the construction of the railway between Mombasa and Lake Victoria, which cuts through Molo, suggests that Turi and Molo was an area that had already attracted African settlement before the colonial rule. There were open grass fields on the gently rolling hills that were surrounded by patches of forest. With ample rains, swamps and several streams passing through, Turi and Molo were fertile because of good soils and a steady supply of water, but the area was not farmed to any significant extent before the colonial period (Kenny, 1981). Holte argues that at first when Africans noted the presence of the white man in Molo, they got concerned since they had heard of white settlers in Njoro who had been given the land that previously belonged to Africans.

The African chiefs assured them that the white men were there to monitor the activities of the Kenya Uganda railway and not to take away African land. However, by mid-1904, land alienation had already started in parts of Mariashoni and Turi (Holte, 2013). Molo was all but thick forest including Bamboo, inhabited by small bands of the hunting and honey collecting Ndorobo. The cool climate $(2,500$ meters above sea level) and ample rainfall encouraged rapid settlement. In 1903, the commissioner Charles Eliot offered free grants of land in Molo, but although potentially arable land of six hundred and forty-acre blocks were taken up, ranches of five thousand acres in Molo were not taken. The settlers who occupied the six hundred and forty acres later moved to Londiani having not engaged in farming or cleared their land. A trickle of settlers, many of South African and British origin, arrived in 1904 and another major allotment of land was made. The first settler started by cultivating large areas of land in Kweresoi (Kuresoi), Mariashoni and later Turi area (Curtis, 1986). In 1904, land was allotted to white settlers in Molo. Dr G. Atkinson and Mr E.C Atkinson were granted farmland in Turi. $\mathrm{Dr} \mathrm{G}$. Atkinson and $\mathrm{Mr}$ C. Atkinson were granted 20,000 acres that ran along the railway line.

However, instead of engaging in agricultural activities, they turned to sawmill activities and opened Equator sawmills in Turi in 1904. This was due to the availability of full-grown trees that produced the best timber, which could later be sold in Nairobi. The Africans were lucky to secure jobs in the timber factory as labourers (Playne, \& Holderness, 1908). Ewart Grogan was also allotted land in the swampy areas of Turi. Grogan was one of the settlers who continuously appealed for help from the government, as he was very personate about farming. His farmland was approximately 40 kilometres from Turi centre. However, 


\section{Editon Consortium Journal of Arts, Humanities and Social Studies (ECJAHSS)}

Volume: 01 Issue: 03 | Sep -2019

ISSN: $2663-8525$

Received: 19.08.2019; Accepted 23.08.2019; published: 30.09.2019 at www.editoncpublishing.org

Njuguna, G.W., Editon Cons. J. Arts., Humanit. S. Stud., Double -Blind Peer Reviewed Journal

with few agricultural supervisors in the entire Nakuru district, Ewart was always disappointed and opted to always consult with Delamere, who was farming in Njoro (Holte, 2013). Tanui notes that Africans in Kiptunga village were evacuated from Mariashoni to create space for the settlement of Mr L. Cooper, a white settler.

Some Africans, because of the evacuation, became hostile and resisted the move. As a result, his grandfather was severely injured as he resisted the move. Cooper got a total of 172 acres of land at Mariashoni. He decided to venture in wheat farming. However, in the year 1907, Cooper did not harvest even a single bag of wheat due to wheat rust. During this first plantation, Cooper did not either use manure or any fertilizer. Cooper decided to seek advice from the district agricultural Office and was given Njoro I variety of wheat (Tanui, 2019). The white settlers had entered the district with high expectations, envisaging a better future for themselves as farmers. Most white settlers had not engaged in agriculture before in their home countries. During the early 'trial and error' period, a variety of crops were being cultivated. These crops included barley, wheat, maize and potatoes (Holte, 2013). David Anderson accounts for the conflicts between Africans, European commercial interests and European conservational interests in Ewart Gragans's concession area that was about 40 kilometres from Turi.

His concession was granted in 1904, but African rights in the area were established later and excluded a number of pre-colonial users. Land ownership among the Africans was communally owned. Land tenure was also based on social grouping of the entire community. Occupation of land was through the clearing of bushes. Land was considered an important asset in the community. Moreover, the forest remained a place of refuge for many Africans, some at the margins of colonial law (Anderson, 1984). Major Bertram Webb was the first European to employ the Okiek as labourers on his farm. In 1907, this farm was incorporated into Keringet farm, a joint venture by Edward Powys Cobb, Jack Hill-Williams and John M. Drury.

This land largely represented colonial investment and experimentation on a large scale. Powys, Drury and Jack bred sheep and cattle, and made the first attempts at industrializing farming in the area. A number of large steam-driven were bought on the railroad to Molo station and transported by ox-cart for roughly 20 kilometres to the farm. With this investment came a commitment to making the area home. The settlers were keen to note that the climate was excellent and suitable for agriculture (Holte, 2013). Nyaboke notes that after her family moved from Kabianga and settled in Elburgon before the colonial rule, they acquired 20 acres of land.

Five acres were put under cultivation, five acres were used for animal rearing, and the remaining ten was full of indigenous trees. In 1908, the family had to be pushed from Elburgon to the swampy areas of Turi where farming was impossible. In the process, her father returned to Elburgon and was badly fought by the white man guards who guarded the mzungu and broke his spinal cord. Nyaboke added that his family lost everything as their house was burnt down, and their livestock taken away (Nyaboke, 2019). This concurs with the argument raised by Mungeam that there was conflict over land between the Europeans and Africans. Intervention by the colonial state on the settlers' behalf was decisive, with a differing view over policy implementation not detracting from the active collaboration between colonial officials and European representatives (Nyaboke, 2019). Kibet, who lived in Mariashoni recounts that land that had been prepared by Africans through cutting down trees, burning shrubs, was later taken by the white farmers. Africans labour was used with the supervision of the colonial administration (Kibet, 2019). Njeri whose parents moved to Rift valley before the WWI recalls very well the stories she was told and how the 


\section{Editon Consortium Journal of Arts, Humanities and Social Studies (ECJAHSS)}

Volume: 01 Issue: 03 | Sep -2019

ISSN: $2663-8525$

Received: 19.08.2019; Accepted 23.08.2019; published: 30.09.2019 at www.editoncpublishing.org

Njuguna, G.W., Editon Cons. J. Arts., Humanit. S. Stud., Double -Blind Peer Reviewed Journal

land their parents had settled in was taken away from them.

They (referring to the police officers) rooted everything, burnt the house and killed all our sheep. My parents were left beggars with nowhere to go. All that they had struggled to acquired was turned down to ashes in minutes (Njeri, 2019).

The colonial chiefs provided a link between the local population and the colonial administration (Wolff, 1970). A chief was a direct agent of the government in his location. All over Kenya, every chief had certain general functions and duties that went hand in hand with his appointment. Among these duties was to maintain the spirit of loyalty to the British Crown, and to inculcate such spirit to see that all lawful orders are obeyed by the African inhabitants of his location, collecting taxes and recruiting labourers (Government Monographs, Report and Research Work, 1912). Although the powers and duties of the chiefs gradually evolved, the basic legal framework on which the authorities of chiefs rested derived from two ordinances enacted before the First World War. A 1902 ordinance gave the chiefs three broad responsibilities. Chiefs were to maintain law and order and could be subjected to fines if disturbances occurred in their areas of jurisdiction (Regulations on Kenya Colony, 1902). The protectorate restricted Africans to the specially demarcated reserves whose conditions effectively denied Africans any chance of competing with Europeans agriculture and/or obtaining the cash crop for taxes without wage labour.

The expertise at the disposal of the Kenya department of agriculture went almost exclusively to Europeans farms. In 1903, the colonial government assumed responsibility of developing commercial agriculture in the country. To achieve this, the Department of agriculture was established. During these early years, the department was mainly concerned with the agriculture problems faced by
European farmers. For the settlers, the colonial Kenyans economy provided land and labour at uniquely low costs. The political power favoured the Europeans. The financial system twisted and distorted to serve the needs of a minority who were the Europeans. This led to an increasing deterioration of the condition of the majority of the inhabitants who were Africans (Regulations on Kenya Colony, 1902). Onesmus Kirebi remembers fifty acres of land that was located in the East side of Molo that was given to mzungu in the early colonial period. His grandfather was among the Africans who were affected as he had three acres under millet and six acres on maize, which was slashed and burnt before maturity. Not only his grandfather's farm was burnt down but close to one hundred acres were burnt down under the supervisor of the colonial authority. Constant patrol by guards hired by the white settlers was carried out to ensure that no African was seen in the fields cultivating (Kirebi, 2019). According to Richard Munyua, African workers were living in the outskirts of the settlers' farm and in the nearby forest during the first decades of European settlement in the highlands.

They were not able to keep livestock on the land. Turi, as elsewhere in the highlands, had been divided into properties that were owned by white settlers (Munyua, 2019). By moving African houses away from the European houses, Africans were excluded from view and by extension, consciousness (Epperson, 1990). This, according to Duder, created a view of a European landscape. To the extent that Europeans regarded their African workers as "living in a separate mysterious world of their own" (Duder, 1993). The newly fifty dukas (small stores) and market centre that constituted the trading centres were constructed on the slopes above the road in Turi. The trading centre was organised around a central square. Turi market was the location where farmers sold their local agricultural produce. Turi market was in between Molo and Elburgon. Most of the buildings were single-story buildings 


\section{Editon Consortium Journal of Arts, Humanities and Social Studies (ECJAHSS)}

Volume: 01 Issue: 03 | Sep -2019

ISSN: $2663-8525$

Received: 19.08.2019; Accepted 23.08.2019; published: 30.09.2019 at www.editoncpublishing.org

Njuguna, G.W., Editon Cons. J. Arts., Humanit. S. Stud., Double -Blind Peer Reviewed Journal

of concrete construction that were not painted. Few shops were painted in vivid colours and advertised for corporations.

Africans who were not allowed to settle at the highlands and were only restricted to the African reserves and offered their labour to the white farms. This resulted in landlessness among the Africans as a slight population increase resulted in population pressure on those reserves (Duder, 1993). However, the migration in and out of the reserves was to be put under control in order to restrict the migration of labour. It was argued that this would make it easy to control the indigenous people than would be the case if they were scattered all over the country. The African labourers were not allowed to keep livestock in the Nakuru district as it was thought it would result to competition between the Africans and the white settlers or even diseases like rinderpest would spread to white settlers' farm. A number of Africans were also lucky as they were allowed to farm a certain farm size. Settlers in Molo allowed their labourers to farm and keep livestock. Mr M. Vale allowed his labourers to keep livestock. It was noted that one of his labourers had up to 250 sheep and 7 cows. Labourers who sold their produce to other Africans who lacked enough to eat cultivated Land that remained uncultivated in Mr Vale's farm. Mr Allen too allowed labourers in his 150-acre farm to keep livestock. Allen allotted small plots to each of his labourers. Nakuru district commissioner was against this move and discouraged $\mathrm{Mr}$ Allen on his idea. Mr Allen argued that once the labourers were comfortable and happy, they would work hard on the farm; hence, his produce would increase. However, Kibet (2019) reports that there were settlers who did not allow their labourers to live in their farms live alone to farm.

\section{Conclusion}

Before the invasion of Kenya, the Africans were leading a traditional life. At first, Africans were not willing to give off their land to the white settlers, and this resulted in the use of force. Land was communally owned. A piece of land could be cultivated until the soil fertility was exhausted. The land was left to lie fallow to regain its fertility. In order to alienate the land for the settlers' benefits, the colonial government issued circulars, and regulations, and established a judicial system to improve order and confiscate land with the force of law. White settler farms were carved out of the most fertile soil in the highlands. The settlers were expected to clear and farm the land. However, some settlers turned to business by cutting down trees and selling timber in Nairobi. Africans offered their labour in the settler farms.

The colonial state relied on African chiefs for the maintenance of order, collection of taxes, mobilization of labour, and enforcing commodity production than importing "chiefs" from Britain to perform these duties. Several campaigns took place to lure new settlers to Kenya, one which included posters that advertised 'settlers in Kenya, Britain's youngest and most attractive colony'. Low prices were offered to fertile lands. Africans labourers, due to various measures imposed by the colonial government such as the imposition of tax, were obliged to work for the European settlers. Not only were the Africans stripped of their lands, but they were also deprived of their rights to move freely in their country and to choose the kind of labour they wished to offer. Before the introduction of the kipande system in 1915, there was the introduction of a poll tax in 1910. The poll tax required all adults over the age of sixteen years to pay tax. Africans who could not make to pay tax sold their livestock or agricultural produce to meet the requirement. The Kipande system was introduced in 1915. All labourers were supposed to carry the Kipande, which was usually hanged in their neck. It contained the details of their employers, their pay and their fingerprint. This made it hard for an employer to change from one employer to another. The Kipande system was an invention of the British colonial system whose role was to 
Editon Consortium Publishing

Transforming Scholarly Publishing

\section{Editon Consortium Journal of Arts,} Humanities and Social Studies (ECJAHSS)

Volume: 01 Issue: 03 | Sep -2019

ISSN: $2663-8525$

Received: 19.08.2019; Accepted 23.08.2019; published: 30.09.2019 at www.editoncpublishing.org

Njuguna, G.W., Editon Cons. J. Arts., Humanit. S. Stud., Double -Blind Peer Reviewed Journal

control the mobility and disposal of the African labourers to put them at the service of the white settlers.

The colonial period in Molo saw the introduction of crops such as Hickory King Maize variety, pyrethrum, wheat and Coco beans. The white maize was mostly preferred to its low cost of production since it did not require a big number of labourers. Potato varies such an Anett, and Kerr pink were also farmed in Molo. However, in most cases, farmers did not go for the hybrid potato; instead, they selected the best in size and preserved them for planting in the next season.

\section{References}

Best, N. (1970). Happy Valley: The story of the English in Kenya. London: Secker and Warburg. Cone, W., \& Lipscomb, J. (1972). The history of Kenya agriculture. Nairobi: University Press of Africa. Curtis, A. (1986). Memories of Kenya: Stories from pioneers. Nairobi: Evans Brothers Limited.

Duder, J. (1993). Men of the officer class: The participants in the 1919 soldiers' settlement scheme in Kenya. African Affairs 9.

Epperson, T. (1990). Race and the disciplines of the plantation. Historical Archaeology 24(4).

Holte, B. (2013). St. Andrew Turi. MA Thesis, University of Oslo.

Huxley, E. (1957). No Easy way. Nairobi: East African Standard.

Kanogo, T. (1987). Squatters and the roots of Mau Mau 1905-1963. Nairobi: East Africa Educational Publishers.

Kenny, M. (1981). 'Mirrors in the forest: The Dorobo hunter-gatherers as an image of the other,' African Journal of the International African Institute, 51(1), 477-480.

Kenyanchui, S. (1992). European Settler Agriculture. In Ochieng, W., \& Maxon, R. (Eds). An economic history of Kenya. Nairobi: East African Educational Publishers Limited.

Kibet, Amos M Turi 20 April 2019

Kirebi, Onesmus $\quad M \quad$ Elburgon 13 March 2019

Levin, J. (1960). The Export economies: Their pattern of development in historical perspective. Massachusetts: Harvard University Press.

Muiruri, P. (2013). The social, cultural and economic impact of ethnic violence in Molo 1968-2008. MA Thesis, Kenyatta University,

Munyua, Richard Molo M $\quad$ M April 2019

Myint, H. (1964). The Economies of developing countries. London: Hutchinson Publishers.

Njeri, Eunice $\quad$ F $\quad$ Mariashoni 15 April 2019

Nyaboke, Magdaline F Mariashoni 19 April 2019

Ochieng, W. (1989). A Modern history of Kenya 1895-1980. Nairobi: Evans Brother Kenya Limited.

Playne, S \& Holderness, G. (1908). East Africa (British): Its history, people, commerce, industries and resources. London: The Foreign and Colonial Compiling and Publishing Company.

Powys, W. (1969). The story of sheep farming in Kenya. East African Agricultural Journal, 2, 18-19. 


\section{Editon Consortium Journal of Arts, Humanities and Social Studies (ECJAHSS)}

Volume: 01 Issue: 03 | Sep -2019

ISSN: $2663-8525$

Received: 19.08.2019; Accepted 23.08.2019; published: 30.09.2019 at www.editoncpublishing.org

Njuguna, G.W., Editon Cons. J. Arts., Humanit. S. Stud., Double -Blind Peer Reviewed Journal

Tanui, Nicholas M

Molo

13 April 2019

Government Monographs, Report and Research Works (1912). Ordinance to make provision in regard to powers and duties of native chiefs, No.22, PRO Co 633/3.

Regulations on Kenya Colony (1902). No. 22.

Towett, J. (2004). Ogiek land cases and historical influence 1902-2004. Nairobi: Ogiek Welfare Council. Wolff, R. (1970). Economic aspects of British Colonialism in Kenya 1895-1930. New York: Yale University. Wringley, C. (1965). 'Kenya: The patterns of Economic life 1902-1945.' In Harlow, V., \& Chilver, A., (Eds), History of East Africa. London: Heinemann Publishers.

Wunyambari, M (1993). Mau Mau and Kenya. Nairobi, East African Educational Publishers.

Zwanenberg, R.M.V. (1975). Colonial capitalism and labour in Kenya. Nairobi: East African Literature Bureau. 